\title{
Causes and Consequences of Divorce in Bangalore City - A Sociological Approach
}

\author{
Ramachandrappa. S \\ Research Scholar, Department of Sociology, Bangalore University, Bangalore - 560056.
}

\begin{abstract}
In the recent years a steady increase in incidence of divorce has been noticed in Metropolitan cities in general and in Bangalore city in particular of India. Every year, almost 2000 to 3000 divorce petitions are filed and almost similar numbers are disposed off in the family courts. It is observed that there has been a consistent rise in the incidence of divorce, about 17.25 percent from 1991 to 2000, which further increased to 31.9. Percent in 2001, onwards, indicating a rise of 14 percent during the decade. It appears that marital dissolutions in metropolitan cities and Bangalore cities increasingly influenced by incompatibility among young couples and several other factors, led to dissolutions, thereby threatening marital bonds. The expectation of young couples from marriage is growing for their emotional and social problems are very difficult to be met. This paper is concerned with both explanatory as well as analytical goals, it is particularly concerned with investigating the family structural dimensions of marital disruption and it tries to explore the factors that have lead to divorce and ideates types of person who opt for divorce, in Bangalore city.
\end{abstract}

Keywords: conjugal, commonness, intimates, magnitude, trouble, wastefulness.

\section{Introduction}

Family is the most important primary group in society. Family and marriage are considered to be the two pillars of any society and as such they are the two most important societal institutions. In India, traditionally and from time immemorial, marriage has been allowed as sacred; and marriage for most Indians is not merely a sacrament but is sacrosanct. Once the couple enters into the bond of marriage, the relationship is considered perpetual-till death does them apart. In other words, marriage used to be for life and it worked as a bulwark against social vulnerabilities. It had an inbuilt system of checks and balances, and roles and priorities were defined by the society for the couple. What distinguished marriage in India from marriage in the West was the sanctity attached to marriage: a sense of perpetual bonding and an element of divinity in it.

Marriage is an institution which admits men and women to family life. Marriage is defined as a socially sanctioned union of male and female or as a secondary institution devised by society to sanction the union of a male and female for the purpose of establishing a household entering into a conjugal relationship and procreation. Marriage is one of the most important events in one's life affecting the physical status as well as psyche of an individual (Mazumdar, 2001).

According to Hindu-law, marriage is a sacrament, an indissoluble union of flesh with flesh, bone with bone, to be continued even in the next world and life. Marriage is one of the socially sanctified practices for attainment of moksha. It is considered as performance of religious duties and begetting a son enables him to get deliverance form the suffering of hell. Marriage was is not a contract but an indissoluble tie, solemnized once and for all.

Marriage though varies in age, customs and rites, it is considered as an enduring sub-system of larger supra-system, the society across the cultures in all civilized countries. In olden Hindu law there was nothing like divorce except in lower castes and in exceptional cases like extramarital relationships and insanity, Divorces and separation, specially divorced women were despised and treated in very inhumane ways.

But Hindu marriage act 1955 and its amendments in 1975 have brought some changes in the concept of Hindu marriage. According to this Act marriage is a socio legal concept. And like any contract, liable to be dissolved. The sacramental coloring is lost. Marriage can be dissolved under certain grounds.

Recent changes in the society like rapid industrialization, urbanization, migration and mass-media, have brought tremendous changes in the concept of marriage and divorce. In Indian families also it no legislation of divorce, increased self-centeredness, blind borrowing of western style has caused change in the attitudes towards marriage and divorce, in India also.

Divorce is related to 'marriage and 'family' which are the most important institutions of human society. Divorce is the legal dissolution of marriage and it has great socio-cultural implication. Divorce is also viewed of social invention and a socially devised means of dealing with marriage failure.

The phenomenon of divorce, however, is not new to India, and it has existed at all times in known history. But it was resorted to only in extreme cases where there was unbearable cruelty, desertion, mental illness, impotence/infertility, and infidelity. But it is no longer so. 
Divorce is almost a new concept among the Hindus, for the characteristic quality of Hindu marriage was that it was a union for life. The Hindu women have been asked to put with all sorts of repressions and suppressions in the name of the honour of a family and for the good of the children. It was generally argued that if legislation was allowed to interfere with the sacrament of marriage, the institution of marriage will break down. It was in this background that the Hindu marriage Act, 1955, was passed with several amendments, particularly 1976 amendments making a provision for divorce by consent also.

The impact of legal dissolution of marriage on the institution of family and the total society is a matter of difference of opinion. According to some, divorce is the most practical index of family disintegration; divorce is also recognized as a serious social problem. However it can safely be said that divorce is one the many sings of family is said that divorce is one of the many sings of family disintegration and it represents the final one. Divorce has far reaching consequences with regard to persons, social institutions and communities.

\section{CONCEPT OF DIVORCE}

The word 'Divorce in English derived from the Latin word divertive which again is derived from 'Dis' which means 'apart and vertere which means to turn Divorce is the dissolution of the tie of marriage. So divorce is the turning away of partners from each other. It truly is a complete turn from the way of life the couple had so far. Divorce in the proper and strict sense of the term means complete rupture of the marital bond; the persons divorced returning to their original state of being free to marry.

Divorce represents the end of the hopes that two people had for each other, it is the certificate that their relationships failed. According to the Hindu Marriage Act, 1955 (amended up to 1976), any marriage solemnized, whether before or after the commencement of this Act, may on a petition presented by either the husband or the wife, be dissolved by a decree of divorce on the grounds mentioned therein. The concept of divorce may be understood as different form such terms as a). Separation b) Desertion and c) Annulment

Separation may be an informal preliminary step towards divorce, a temporary expedient to lessen the immediate conflict, or a legally recognized to lessen the immediate conflict, or a legally recognized decision to live separately without divorcing. Marital separation means, one deprived of normal marital association, affecting their health, security and happiness for the children there is the loss of daily love and conical of one parent.

Desertion: as the term is ordinary employed, means "the irresponsible departure from the home on the part of either husband or wife, leaving the family to fend for itself.' several students have shown the deserters are husbands form the lower economic groups. Desertion is an evasion of marital responsibilities and hence, we have no way of ascertaining its true extent. Many of the consequences of desertion are similar to those of divorce, for the family may be permanently dissolved. Desertion, however, presents a few special problems. Emotionally, the wife and children often suffer much more severely than in the case of divorce.

Annulment: is a court decision that the marriage contains some legal flaw (coercion, fraud, unwillingness to consummate the union, homage, bigamy etc,). Nimkoff defines annulment is a legal action that invalidities the marriage on the ground that it never legally existed and should not have occurred.

In separation, the spouses are legally recognized as living in separate households but are not free to remarry sine they attain their marital status. Desertion is the voluntary withdrawal of one marriage partner from the other without the latter's consent, while nullity is the legal recognition that a marriage had not in fact been valid.

\section{MARRIAGE AND DIVORCE IN BANGALORE CITY}

Divorce is most prevalent between the age of 20-30.Globally divorce statistics reveal that Sri Lanka 1.5 percent, Japan 1.9 percent, Italy 10 percent, Canada 37 percent, France 38.3 percent, united kingdom 42.6 percent, Russia 43.3 percent, Denmark 44.5 percent, united nations 54.8 percent, Sweden 54.9 percent etc. In India the rate is very low, only 1.1 percent But the divorce cases are in an increasing trend among professionals at Bangalore.

Bangalore is becoming the divorce capital of India with about 300 in every 1,000 married couples seeking separation from their partners. While 11 out of 1,000 Indian marriages end in divorce compared to the whopping figure of 400 out of every 1,000 in US, the statistics in Bangalore alone is scary. About 40 divorce cases get filed at the family court every day on an average and each case takes a minimum of three to five years before it closes.

The phenomenon of divorce, however, is not new to India, and it has existed at all times in known history. But it was resorted to only in extreme cases where there was unbearable cruelty, desertion, mental illness, impotence/infertility, and infidelity. But it is no longer so. 


\section{OBJECTIVES}

$\checkmark \quad$ To study the situation of the divorce phenomena for Bangalore Metropolis for the period 1991-2001, from the family court records.

$\checkmark$ The consequences of divorce on his/her socio-economic status of the divorce.

$\checkmark \quad$ The study is directed to upper and lower middle status family.

\section{STUDY AREA}

Bengaluru (Silicon Valley of India) metropolitan in the southern part of Karnataka, India and covers an area geographical area of $741 \mathrm{~km}^{2}$ with a population of 5.8 million (censes 2001). Today as a large city and growing metropolis, Bangalore is home to many of the most well-recognized colleges and research institutions in India. Numerous public sector heavy industries, software companies, aerospace, telecommunications, and defense organizations are located in the city. Most of the women population in Bangalore depend on home based assignments and garments. Bengaluru is well known for information technology, Capital for Bio technology industries, Service industry center, Education center for medicine, Engineering, Rapid Infrastructure Development and etc.... But city is struggling to cope with overcrowding, infrastructural issues and this has affected living in modern cities.

\section{Methodology}

Data were gathered through the use of structured questionnaire and oral interview (Ram Metha et.al). Hundred (100) copies of questionnaire were administered to the marital disruptions divorce, desertion, separation, in various parts of Bengaluru city. The questionnaire covered socio-economic status of the divorce couple. Hundred (100) respondents were randomly selected from equal ratio of both the gender, male (50) and female (50) ITOs and BPOs teachers, business, literates, social welfare officers and other public servants were the respondents in this sample study which was a part of my research Questionnaire consisting of twenty (20) items were administered and which was a co-operative effort done with the respondents.

\section{Results And Discussion}

For the present study, total 100 divorce case in that 50 female and 50 male were interviewed in Bangalore city. After studying 50 cases of divorce in much detail the researcher feels that the real reason for divorce in many cases is lack of understanding and communication between the spouses. Marriage is an intimate relationship between a man and a woman, if real love and understanding exist between two people difficulties and problems are overcome. Such a union cannot be shattered by temporary problems. Where the husband wife relationship itself is not very deep, problems are magnified and may disintegrate ending in ultimate rupture. The only way to prevent divorce is to encourage a young couple to understand each other and communicate freely so that tensions do not pent up and create irrevocable situations.

The Information Technology boom in Bangalore is not unknown. However, everything comes with a price. Statistics reveal that in 2006 alone, 1,246 cases of divorce pertaining to those in the IT sector have landed in the matrimonial courts in Bangalore. Financial freedom, lack of time at home, erratic working hours, work pressure, financial security and stress are being seen as the main reasons for this fiasco.

The worrying factor is that the number of divorce cases pertaining to those in the IT sector has seen a steady rise since 2003. In 2003, the number of cases from the IT sector was 283 while in 2004 it went up to 526. Statistics available show that in 2005 the figure went up to 946 and in 2006 the figure was 1,246. The year 2007 has not been too kind. The statistics available till June 2007 state that the number of divorce cases from the IT sector is 828 already. Experts state that the figure is likely to increase by the end of the year. What is more shocking is that divorce cases from the IT sector seem to be contributing to the number in a big way.

In the recent year 2003, the total number of divorce cases, including the ones from the IT sector was 1,280 while in 2004 it was 1,240. In 2005 and 2006, the figures were 1,860 and 2,493 respectively. The State Women's Commission has woken up to this issue and states that drastic measures have to be taken or else there would be more single persons that married couples in the city.

The Chairperson of the Commission Pramila Nesargi says that in most cases she has come across, marital discord is due to an unhappy physical relationship. "Viewing the computer for long hours has proven to cause impotency," she adds. She also says the commission is planning to visit the IT companies and take stock of the situation. She says she wants to inspect working conditions and would also make suggestions to change the working pattern of the employees so that they get more time at home.

Vishwanath B N, an advocate who is handling at least five cases pertaining to couples from the IT sector, says that these couples do not even try to reconcile and are in a hurry to end the marriage. There is very little that can be done to save the marriage after it comes to courts. Something ought to be done to try and prevent the marriage from breaking up. Sanjanthi Sajan, who runs a boutique matrimonial firm in Bangalore which has handled several such cases, says that at her firm the basic idea is avoid reaching the courts. 
She says that she has hired counsellors who will talk to couples to avoid going in for a divorce. The pendency rate in such cases is not high either. Out of 3,829 cases relating to the IT sector from 2003 onwards till date, around 1,700 cases have been disposed of thanks to the couples opting for a mutual consent. The remaining cases are pending since as per the matrimonial law, one year time is granted for reconciliation.

\section{Conclusions}

Divorce is becoming common in all cases of the Hindu society. Family members of the lower castes or classes approach the judicial courts for obtaining divorce. Yet different forms of marital disruptions like separation and desertion as well as customary divorce are common among them. Most of the Hindu castes still treat divorce as a social stigma and criticize individuals for opting for it. Education has widened their horizons and ability thinks and rationalizes. Despite higher education and employment of women love marriage are comparatively few in number, the main reason is this appears to be marriage at relatively early age. It is also noticed that most of the Indian males are still traditional in their outlook in matters of marriage and they depend upon elders for the selection of bride.

The early days of marriage are extremely important and crucial in relation to martial adjustment. It many cases, it is noticed that marriages are disrupted right at this phase. Divorce is usually a product of multiple factors - personal, familial and environment at work simultaneously with the changes in legislation, public opinion, weakening of tradition and religion as well as emancipation and economic independence of women, divorces and remarriages are likely to increase.

Except in cases of mutual consent, divorce is still a cumbersome costly affair. Many a time, it is observed that a spouse who is not interested in legal decree can prolong a case for years. Thus wasting precious years for the other spouse after divorce men face relatively fewer problems as compared with women. The Indian society is still partial towards in its attitude towards men. Men continue in their joint family as a result, home management of even care of the children poses no great problem.

Remarriage rate is much higher in men. Several of them did not wait for a legal decree of divorce and started living with anther spouse with or without marriage. In most cases, where children were present, it was the mother who kept the children. The care of the children was an important deterrent in divorcee-female's remarriage. Divorce is more common among childless couples. Divorce results in acute emotional problems. Longer the duration of a marriage, greater is the trauma produced. In this aspect women suffer much more than man. Many women are just house wives and they have no place to go no body to talk to. Parents and relatives may be highly critical. Children of divorcees do suffer in various ways if not physically at least emotionally due to the absence of one parent.

\section{References}

[1] Mazumdar, K. 2001, Dowry related Violence: An Overview, The Indian Journal of Social Work, 62 (3), $397-413$.

[2] Metha Rama, 1975: Divorced Hindu Women, Vikash Publishing House Pvt., and New Delhi.

[3] Padmasini, V. 2003. Growing Divorce Rate in India. South Asian Women's Forum. 10 March.

[4] Pothan.S(1986): Its Causes and Consequences in Hindu Society, Vikash Publishing House, PVT, LTD India

[5] Shah, A.M. 1998 The Family in India: Critical Essays, New Delhi: Orient Longman.

[6] News. Telegraph 2005. Divorce Soars in India's Middle Class. 1 October

[7] Krishnakumari, N.S. 1987. Status of Single Women in India. (A study of spinsters, widows and divorcees). New Delhi: Uppal Publishing House, Joint's Women's Programme Publication.

[8] Goode, William J. 1963: Family Disorganization in Contemporary Social Problem(ed) R. K Merton\& Robert A Nisbet, London

[9] Choudhary, J.N. 1988. Divorce in Indian Society. A Sociological Study on Marriage Disruption and Role Adjustment. Jaipur: Print well Publishers.

[10] Devi Prasad, B. (Ed.). : 2001 Special Issue on Family Violence,

[11] Devi, Usha R. 1998. Divorced Women. Socio-Psychological Problems. New Delhi: APH Publishing Corporation.

[12] Nanjappa, V "The Rising divorce rate in the IT Sector"

[13] Nanjappa, V., "Bangalore is the most stress out city"

[14] Nair, P.T. 1978.Marriage and Dowry in India, Calcutta: Minerva Associates. 